\title{
Investment and Growth Amidst Widening Government Debt: The Ghanaian Story
}

\author{
Eric Boachie Yiadom* Richard Fosu Amankwa \\ University of Professional Studies, Accra, P. O. Box LG 149, Legon - Accra
}

\begin{abstract}
The study revisits the debt-growth nexus and broadens the argument to examine the unique effect of government debt on investment in Ghana. Data from World Development Indicators on the Ghanaian economy were sampled from 1990 to 2015. The empirical results from the Multiple Linear Regression (MLR) suggest an inverse relationship between government debt and economic growth in Ghana. In addition, a percentage increase in government debt reduces investment by $0.65 \%$; implying that government debt harms investment due to fungibility of debt and accompanying debt repayment responsibilities. Policy ramifications resulting from the study are that the Ghanaian government should restructure public debt management to eliminate debt fungibility and reduce debt to GDP ratio as well.
\end{abstract}

Keywords: investment, growth, government debt, Ghana, debt fungibility

DOI: $10.7176 /$ RHSS/9-3-07

\section{Introduction}

The constant returns to scale condition of the Solow-Swan neoclassical growth theory advances that doubling the rival inputs leads to doubling output; inferring that a large inflow of resources (for example capital) is a necessary condition to achieve growth. This generalization has resulted in ideological differences among various economists on the effect of increasing capital flows on macroeconomic indicators. Whereas extant empirical studies (Eberhardt \& Presbitero, 2015; Gui-Diby, 2014; Sulaiman \& Azeez, 2012; Sedik \& Sun, 2012; Mody \& Murshid, 2011; Aizenman \& Spiegel, 2006; Sachs et al., 2004) support this assertion; other evidences especially from SubSaharan Africa (SSA) suggest contrasting results in the absence of some mitigating factors (Mensah, Bokpin, \& Boachie-Yiadom, 2018; Agbloyor, Gyeke-Darko, Kuipo, \& Abor, 2016; Zouhaier \& Fatma, 2014; Panizza \& Presbitero, 2014; DiPeitro \& Anoruo, 2012; Presbitero, 2008).

The seminal work of Solow (1956) on 'contributory to theory of economic growth' also confirm that countrywide growth rate is determined by the savings rate, incremental output-capital ratio, depreciation and population growth. He explains that the rate of growth depends on the rate of investment in these growth factors. Unfortunately, Ghana's growth challenges epitomize scanty investment in these factors. Sachs et al. (2004) and Collier and Dollar (2002) confirmed an earlier assertion by Chenery and Strout (1966) that developing countries do not have the needed resources to spur investment in the growth factors that could subsequently propel expansion in output. Particularly, Sachs et al. (2004) associate developing countries growth challenges to low capital threshold, savings trap and demographic trap. The lack of resources according to Chenery \& Strout (1966) creates a "two gap" model. The "two gap" is identified to be the savings gap and the import gap. The savings gap is the gap between the level of domestic savings needed for investment and the required level of investment for a targeted growth rate. The import gap on the other hand, is the differences between foreign exchange earnings and import required to achieve a certain level of output and at any moment in time, one gap is binding, and government debt fills that gap (Easterly, 2003). Beside the worsening budget deficit experiencing by the Ghanaian economy, the World Bank (2015) is of the opinion that the country needs at least US\$1.5 billion each year for the next 10 years in order to address its infrastructural challenges. Recently, another report pecked Ghana's annual housing infrastructure deficit cost at US\$90 billion (Essabra-Mensah, 2018). Obviously, these funds can scarcely be raised through domestic taxes. Successive governments' attempt to solicit for more funds to invest in the development agenda of Ghana is pushing the country into a timing debt crisis. Lately, there is evidence of large borrowing by the Ghanaian government. Ghana's public debt as a percentage of GDP which fell from $112 \%$ in 2000 to $26 \%$ in 2006 due to debt cancelation is on the rise again with a current ratio of $72 \%$ (World Bank, 2017). These large borrowings are intended to cushion the country's consistent budget deficit. For over 25 years the government's Gross fixed capital formation requirement has stood at 22\% of GDP whereas domestic savings is lagging at $15 \%$ leading to the economy running an average annual budget deficit of 7\% of GDP (World Bank, 2017). It is clear that government borrowing is necessary for the government in order to meet budgetary promises. Debt is not entirely bad as some studies have painted it (DiPeitro \& Anoruo, 2012; Easterly, 2003; Collier \& Dollar, 2002) but it depends on how the debt is used. If government debt goes into the right investment, it could pay for itself and trigger growth. However, poor debt management and debt fungibility is a greater concern in Ghana that deprives the economy from reaping the dividends associated with debt. If debt is not properly managed it correlates negatively with investment and eventually retards growth. This is because the domestic portion of government debt has the tendency of crowding out private investment. In a private sector driven economy like Ghana, if 
business activities in private sector slows down it affects the entire economy. There is extant literature that has examined the debt-growth nexus. Unfortunately, most of these studies focus narrowly on external debt impact on economic growth, neglecting the fact that domestic debt may negatively influence investment and growth. Also, large segment of the literature offers generalized cross-country analysis which makes it difficult to identify the country specific context. This study solves these problems by examining the effect of total government debt on economic and investment in Ghana.

\section{Literature Review}

The Solow growth model offers explanation to the dynamics in growth economics. In this model, increasing the quantity of inputs (say capital) lead to increase in national output. Solow explored the behavior of the economy as it steadily grows through time. In particular, he looked at the relationship between the labor force growth, capital growth and technological growth and examined whether the growth process has any inherent tendencies to slow down. The model focuses on four variables: aggregate output(Y), capital (K), labour (L), and technology (A). At any time, the economy has some amount of capital, labour and technology, and these are combined to produce output. Two features of the production function should be noted. First, time does not enter the production function directly, but only through $\mathrm{K}, \mathrm{L}$, and $\mathrm{A}$. that is, output changes over time only if the inputs into production change. In particularly, the amount of output obtained from given quantities of capital and labour rises over time, there will be a technological progress only if the amount of knowledge (technology) increases. Second, A and L enter multiplicatively. AL is referred to as effective labour and technological progress that enters into this function is known as labour-augmenting or Harrod-neutral. This way of specifying how A enters, together with other assumptions of the model, will imply that the ratio of capital to output $(\mathrm{K} / \mathrm{Y})$ eventually settles down. In practice, capital-output ratios do not show any clear upward or downward trend over extended periods. In addition, building the model so that Harrod-neutral ratio is eventually constant makes the analysis much simpler. For convenience it is assume that the product of $\mathrm{A}$ and $\mathrm{L}$ is constant throughout. The neoclassical Solow growth model form the basis for many countries' sourcing for large capital resources to spur growth. The model proposes 'common sense' phenomenon; thus, a country's level of input determines its level of output. Therefore, a country seeking to increase output should focus on enlarging it input resources. The three input (technology, capital and labor) within the model can simply be reduced to capital. This is because funds are needed to acquire technology. Labor which seem to be independent of capital is not entirely free, because the dividend on human capital can be fully utilized if labor has been properly trained. This training in the form of education require funds. Reducing the Solow model to capital implies that the other input factors need capital investment to function properly and hence a country that lacks capital investment would see a dwindling growth. In Ghana and Africa at large, such capital requirement for growth investment can hardly be obtained through domestic taxes. Borrowing therefore becomes the gateway to sourcing capital to fund the desire growth.

The two main components of government borrowing are external and domestic debt. External debt constitutes debts owed to nonresident individuals, firms and governments. Domestic debt on the other are borrowings from the residents of a country through the issue of treasury bills, bonds and direct market borrowing from banks and other institutions. Each of the two components has it unique feature. Whereas domestic debt could destabilize local investments and push lending rate and inflation upwards; external debt suffers from exchange rate volatility. As Beaugrand, Mlachila, and Loko (2002) had noted, domestic debt tends to have a crowding-out effect on private investment and thus penalize economic growth. In addition, the government's recourse to domestic financing reduces the supply of loanable funds. In countries where interest rates are relatively flexible, the upward pressure on real interest rates leads to a decline in private investment (Christensen, 2004). Due to these adverse effects, if debt is not properly managed it may worsen the economic fundamentals of the host nation (Mensah, Bokpin, \& Boachie-Yiadom, 2018).

Various empirical studies have suggested the existence of unmitigated direct positive or negative effects of government debts on investment and economic growth. Others also maintain the presence of contingency effect; implying that the influence of government debts on growth is through some other factors. More also, there is a methodological disconnection in the empirical literature. Whereas some researchers argue that the debt growth nexus is best captured by non-linear models; others, however, continue to assume a linear relation between external debts and growth.

DiPeitro and Anoruo (2012, p. 416) examine the impact of government size and public debt on real economic growth, for a panel of 175 countries around the world. Their Hausman test which favors a fixed-effect panel regression shows that both the size of government and the extent of government indebtedness have negative effects on real economic growth. And for that matter "a 1 percentage increase in the size of government on the average reduces real economic growth by approximately 10 percent". Panizza and Presbitero (2014) use the instrumental variable estimation approach to study whether public debt has a causal effect on economic growth in a sample of 17 OECD countries. After controlling for national gross savings (as a share of GDP); population growth; average number of years of secondary education; trade openness; inflation; age dependency ratio; banking crisis dummy; 
and the ratio of liquid liabilities to GDP they report negative effect of public debt on economic growth. Moreover, the empirical investigation of Agbloyor et al. (2016) on a related subject fail to reject the Panizza \& Presbitero (2014) findings that government debts have a negative impact on economic growth. Similarly, Zouhaier and Fatma (2014 p. 445) using Arellano-Bond dynamic panel data estimator explore the effect of debt on economic growth of 19 developing countries over the period 1990-2011. They employ data from World Bank's WDI database and regress different measures of government debts and other exogenous variables (investment, trade openness and inflation) on growth rate of real GDP per capita. They buttress the earlier negative claims of government debts' impact on growth; adding that if the government debt to Gross National Income (GNI) increased by $10 \%$, growth decreases by 0.27 percentage points. They further report a negative coefficient results after interacting external debt and investment. This supports their assertion that "external debt penalizes economic growth by blocking the main channels and growth engines such as investment". In addition, Doğan and Bilgil (2014) use the Markovregime switching model in a study which focuses on government debt growth dynamics of Turkey for the period of 1974 to 2009 and summit that external borrowing has negative impact on growth both in regime at zero and regime at one. Eberhardt and Presbitero (2015) examine the long run relationship between public debt and growth in a large panel of 118 developing, emerging and advanced economies for the period of 1960-2012. Their standard linear regression models results reiterate existing empirical conclusion that there is a negative relationship between public debt and long-run growth across countries.

Other studies have documented that government debt has positive effect on economic growth. Zaman and Arslan (2014) use a time series data over 39-year period to determine the role of government debt on economic growth in Pakistan economy. Arguing that the capital structure of the Pakistan economy is largely financed by government debt. They employ the OLS model and regressed three regresses (External Debt Stock, Gross Capital Formation and Gross Domestic Product) on Pakistan's GDP. Their main finding is that gross capital formation (investment) and external debt stock has significant positive effect on Pakistan GDP. Another study that purports positive relationship between external debt and growth is a paper by Hassan and Mamman (2013). Their findings were not different from Zaman and Arslan (2014). Mishra, Das and Pradhan (2009) asserts that government debts encourage growth financing opportunities and it supports investment finance, imports and consumption so that a country can reach its development goals and economic growth. Abbas and Christensen (2007) also conclude that optimal government debt improves economic outcomes.

\section{Empirical Method and Strategy}

The study is quantitatively designed. Data on the Ghanaian economy over the 1990-2015 periods were sourced form World Development Indicator (2017). The study is bounded with this time period because Ghana received considerable debt relief over these periods. The study estimates the relationship using the multiple linear regressions. Two (2) econometric equations are estimated in order to help answer two important questions:

i. Does government debt affect investment in Ghana?

ii. What is the effect of government debt on Ghana's economic growth?

Equation (1) below answers research question one.

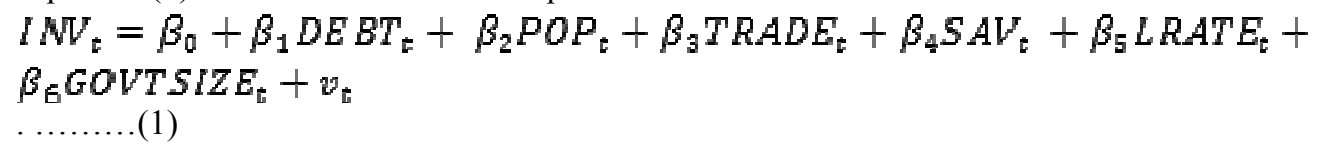

Where;

$t$ denotes time, $I N V_{t}$ represents investment which is Ghana's gross capital formation, $D E B T_{t}$ is total debt stock to GDP, $T R A D E_{t}$ is a measure of total international trade as a percentage of GDP, $P O P_{t}$ is the growth rate of population, GOVTSIZE $E_{t}$ denotes general government final consumption expenditure to GDP ratio, $S A V_{t}$ is the savings growth rate to GDP ratio, $L R A T E_{t}$ represents lending interest rate which is a proxy of Ghana's macroeconomic indicator and $v_{t}$ is the error term. The betas $(\beta)$ are the coefficients of the independent variables after estimation.

On the other equation (2) as specified below answers research question two.

$G D P_{t}-\beta_{1} D E B T_{t}+\beta_{2} P O P_{t}+\beta_{3} T R A D E_{t}+\beta_{4} S A V_{t}+\beta_{5} L R A T E_{t}+\beta_{6} G O V T S I Z E_{t}+v_{t}$ (2)

Where: $G D P_{t}$ denotes GDP per capita and other descriptions of the variables are same as in equation (1) above.

\section{Empirical Results and Discussion 4.1 Descriptive Statistics}

The descriptive statistics in Table 1 shows that the average GDP per capita of Ghana is US\$757.20 over the 26 observations indicating low income country. However, a critical look at World Bank's (2017) WDI data shows that the Ghana's Gross National Income (GNI) has steadily risen into a low-middle income country over the 
periods. From 1990 to 2015 Ghana's average growth rate has been pecked at 3\% per annum. This is an indication that the country is making giant strikes towards economic freedom in the sub-region. Table 1 also shows that investment (INVEST), measured as percentage of gross capital formation to GDP recorded $22.6 \%$ and $30.2 \%$ as mean and maximum respectively. The results show low capital investment to the generation of the growth in the country. It is no surprise that Ghana government continuously source for debt to boost investment.

The debt levels in Ghana is relatively high with a mean of $56.5 \%$ of GDP. The high debt levels do not give opportunity to the government to plan with future taxes. This is because debt make claims on these taxes and therefore the economy needs to rely on further borrowing to survive. This leads to revolving debt cycle as advanced by Mensah, Bokpin and Boachie-Yiadom (2018). The descriptive statistics also show that government machinery capture by GOVSIZE needs at least $12.9 \%$ of GDP to run the economy. Government size is also another form of investment which may have adverse impact on capital investment. In the case of Ghana government size is relatively low. Another important variable in the study is the savings. It could be seen from Table 1 that Ghana's economy has low savings as a percentage to GPD within the 1990-2015 periods. The low savings infer that the needed growth cannot be financed with local funds and hence borrowing becomes inevitable. The macroeconomic proxy - lending rate (LRATE) is quite high with a mean of $21.5 \%$. This is expected in cases where government actively participate in borrowing from local financial market like the Ghana. Government participation creates demand for local loans, leading to interest rate surging upwards. The 1990-2015 periods were also characterized with high population growth rate and unfavorable balance of trade.

\begin{tabular}{|l|r|r|r|r|r|}
\hline \multicolumn{1}{|c|}{ VARIABLE } & OBS & MEAN & STD. DEV. & MIN & MAX \\
\hline GDPPC & 26 & 757.2 & 512.2 & 264.7 & 1827.1 \\
\hline INVEST & 26 & 22.6 & 4.3 & 12.7 & 30.9 \\
\hline DEBT & 26 & 56.5 & 21.7 & 26.2 & 112.0 \\
\hline GOVTSIZE & 26 & 12.9 & 3.4 & 9.3 & 20.9 \\
\hline SAV & 26 & 15.8 & 4.2 & 6.9 & 22.9 \\
\hline L.RATE & 26 & 21.5 & 2.9 & 17.0 & 28.2 \\
\hline POPG & 26 & 2.5 & 0.2 & 2.3 & 2.8 \\
\hline TRADE & 26 & -5.7 & 3.9 & -13.7 & 1.7 \\
\hline
\end{tabular}

\subsection{Correlation matrix}

The correlation matrix reveals a significant negative correlation of about $58 \%$ between GDP per capita and debt, it implies that the more the Ghanaian economy grows the less it should borrow and vice versa. The association confirms empirical findings that debt is relevant at a certain level of growth but when debt exceed a certain threshold it retards growth (Mensah, Bokpin, \& Boachie-Yiadom, 2018; Eberhardt \& Presbitero, 2015; Doğan \& Bilgili, 2014; Panizza \& Presbitero, 2014). Again, the matrix suggests a positive relationship of about $39 \%$ between government size and economic growth. The intuition behind this relationship could be that government's spending on goods and services stimulates private sector investment leading to increased economic activities in the country. As expected, there is a strong positive correlation of about $43 \%$ between investment and per capita GDP; following that increase in investment leads to economic growth. Generally, the pairwise correlation matrix indicates that the presence of multicollinearity is improbable within the dataset.

Table 2: Correlation Matrix

\begin{tabular}{|l|l|l|l|l|l|l|l|l|}
\hline & SAV & GDPPC & INVEST & POPG & TRADE & GOVTSIZE & DEBT & L.RATE \\
\hline SAV & 1.0000 & & & & & & & \\
\hline GDPPC & -0.2320 & 1.0000 & & & & & & \\
\hline INVEST & 0.1401 & 0.4360 & 1.0000 & & & & & \\
\hline POPG & 0.0573 & -0.1137 & -0.5094 & 1.0000 & & & & \\
\hline TRADE & 0.3204 & 0.1502 & 0.7192 & -0.6399 & 1.0000 & & & \\
\hline GOVTSIZE & -0.3523 & -0.3859 & 0.6062 & -0.2704 & 0.2362 & 1.0000 & & \\
\hline DEBT & 0.5119 & -0.5818 & -0.2530 & -0.1550 & 0.0477 & -0.4162 & 1.0000 & \\
\hline L.RATE & 0.0905 & 0.2492 & 0.3058 & -0.2519 & 0.5449 & -0.0611 & - & 1.0000 \\
& & & & & & & 0.3751 & \\
\hline
\end{tabular}

\subsection{Effect of government debt on Investment}

Table 3 shows the multiple linear regression results for the effect of government debt on investment in Ghana. The dataset reveals the presence of significant negative debt-investment nexus. Thus, on the average a US $\$ 1$ increase in debt would cause investment to reduce by $0.65 \%$ holding all other factors constant. This is serious for 
an economy that largely depends on debt. There are several factors that account for this situation. Ordinarily, government borrows to invest, or payoff matured debts and future taxes are used to settle other future maturing debts. Consequently, present borrowings reduce future investment since future taxes are already committed to debt repayment. If present debts are not wisely invested in projects with positive net present value, there would be little funds to invest in the future unless further debt is sourced. There are evidences of poor public investment management in Ghana (International Monetary Fund, 2015), therefore, the abuse of government debt is inevitable. In addition, government borrows to meet other obligations other than capital investment. For example, government may borrow to meet social intervention needs. These debts still need to be repaid from domestic taxes leading to reduction in public investment.

Savings was found to be significant at conventional levels. This does not follow 'common sense' because one cannot spend and save at the same time. However, when time lag is introduced into the discussion, it makes econometric sense that previous savings determines current investment. Therefore, the higher the previous savings, the greater the current investment and vice versa; hence the positive relationship between savings and investment. Trade and government size were found to be significant in the model. There is no debate on the fact that trade improves investment and low government size releases funds for capital investment. Population growth rate and lending rate could enter the model at conventional levels, indicating that the two variables do account for the variations in the investment as far as the equation one is concerned.

Post estimation check using the R-squared and the F-statistics confirm the appropriateness of the model to achieving the research objective.

Table 3: MLR Results: Effect of government debt on Investment

\begin{tabular}{|c|c|}
\hline & (Equation 1) \\
\hline INVESTMENT & Coef \\
\hline DEBT & $\begin{array}{c}-0.6521 \\
(0.303)^{* *}\end{array}$ \\
\hline SAV & $\begin{array}{c}0.2865 \\
(0.1314)^{* *}\end{array}$ \\
\hline POP & $\begin{array}{l}-5.9382 \\
(4.5933) \\
\end{array}$ \\
\hline TRADE & $\begin{array}{c}0.1100 \\
(0.0446)^{* *}\end{array}$ \\
\hline GOVTSIZE & $\begin{array}{c}0.4994 \\
(0.202)^{* *}\end{array}$ \\
\hline LRATE & $\begin{array}{c}-0.2950 \\
(0.292)\end{array}$ \\
\hline CONS & $\begin{array}{c}30.1342 \\
(16.2597)^{* *}\end{array}$ \\
\hline Observation & 26 \\
\hline $\mathbf{R}^{2}$ & 0.7898 \\
\hline $\begin{array}{c}\text { F-Stat } \\
\text { Prob }>\text { F }\end{array}$ & $\begin{array}{l}11.90 \\
0.000\end{array}$ \\
\hline
\end{tabular}

\subsection{Effect of government debt on economic growth}

Model two examined government's debt impacts on economic growth. Although debt maintain the expected negative sign, it however, failed to enter the model at the traditional significance levels. It means that debt is irrelevant in explaining economic growth dynamics in Ghana. This finding is not unique to the current study (Megersa, 2015; Panizza \& Presbitero, 2014). If government debts are not placed in strategic investment, it would not yield the intended results and in cases deteriorate economic growth. It is therefore important that government debts are utilize efficiently to bring growth in the country. From Table 4, trade, savings and government size are relevant in explaining the variations Ghana's economic growth. Again, the post estimation check using the Rsquared and the F-statistics confirm that this model is appropriate for achieving the research objective. 
Table 4: MLR Results: Effect of Government debt on Economic Growth

\begin{tabular}{|c|c|}
\hline & (Equation 2) \\
\hline GDP per capita & Coefficient \\
\hline DEBT & $\begin{array}{l}-0.6127 \\
(0.2149)\end{array}$ \\
\hline SAV & $\begin{array}{c}0.0772 \\
(0.0989)^{* *}\end{array}$ \\
\hline POP & $\begin{array}{l}-3.2777 \\
(1.8080)\end{array}$ \\
\hline TRADE & $\begin{array}{c}0.0014 \\
(0.0256)^{* *}\end{array}$ \\
\hline GOVTSIZE & $\begin{array}{c}0.0592 \\
(0.1905)^{* *}\end{array}$ \\
\hline INT & $\begin{array}{l}-0.0792 \\
(0.2067)\end{array}$ \\
\hline CONS & $\begin{array}{c}14.0991 \\
(6.7997)^{* *}\end{array}$ \\
\hline Observation & 26 \\
\hline $\mathbf{R}^{2}$ & 0.4076 \\
\hline $\begin{array}{c}\text { F-Stat } \\
\text { Prob }>\text { F }\end{array}$ & $\begin{array}{c}2.45 \\
0.0629\end{array}$ \\
\hline
\end{tabular}

\section{Conclusion}

The study has shown that government debt and investment run in opposite direction. This is contrary to policy makers promises of borrowing for investment purposes. The negative effect is associated with poor public investment management. The Ghanaian government has debt fungibility problem which deprives the economy from reaping benefits associated with debt. It has also been established that debt is irrelevant in telling Ghana's economic growth story. Therefore, overreliance on debt retards investment and weakens economic growth. It is important that government maintains active public investment management division backed by statutory instrument to specifically oversee the efficient utilization of government debt. In addition, low savings and government size in the country immensely underpins borrowing. It is important governments maintain low government size to save funds to invest in the productive sectors of the economy.

\section{References}

Abbas, S. A., \& Christensen, M. J. (2007). The role of domestic debt markets in economic growth: an empirical investigation for low-income countries and emerging markets. Washinton DC: International Monetary Fund.

Agbloyor, E. K., Gyeke-Darko, A., Kuipo, R., \& Abor, J. Y. (2016). Foreign direct investment and economic growth in SSA: The role of institutions. Thunderbird International Business Review, 58(5), 479-497.

Aizenman, J., \& Spiegel, M. (2006). Institutional efficiency and the investment share of foreign direct investment. Review of International Economics, , 14(4), 683-697.

Beaugrand, M. P., Mlachila, M. M., \& Loko, M. B. (2002). The choice between external and domestic debt in financing budget deficits: The case of central and West African countries. Washington DC: International Monetary Fund.

Boboye, L., \& Ojo, M. (2012). Effect of external debt on economic growth and development of Nigeria. International Journal of Business and Social Science, 12-31.

Bokpin, G. A., Mensah, L., \& Asamoah, M. E. (2015). Foreign direct investment and natural resources in Africa. Journal of Economic Studies, 42(4),, 608 - 621.

Buchanan, B. G., Le, Q. V., \& Rishi, M. (2012). Foreign direct investment and institutional quality: some recent empirical evidence. International Review of Financial Analysis, 21, , 81 - 89.

Burnside, C., \& Dollar, D. (2000). Aid, Policies, and Growth. American Economic Review, 90(4)., 90(40).

Busse, M., \& Hefeker, C. (2007). Political Risk, Institutions and Foreign Direct Investment. European Journal of Political Economy, 23, 397 - 415.

Chenery, H. B. (1966). Foreign assistance and economic Development. The American Economic Review, 56(4), 679-733.

Christensen, M. J. (2004). Domestic debt markets in sub-Saharan Africa (No. 4-46). Washington DC: International Monetary Fund.

Collier, P., \& Dollar, D. (2002). Aid allocation and poverty reduction. European Economic Review, 46, 1475- 
1500.

DiPeitro, W. R., \& Anoruo, E. (2012). Government size, public debt and real economic growth: a panel analysis. Journal of Economic Studies, 39(4), 410 - 419.

Doğan, I., \& Bilgili, F. (2014). The non-linear impact of high and growing government external debt on economic growth: A Markov Regime-switching approach. Economic Modelling, 39, 213-220.

Easterly, W. (2003). Can foreign aid buy growth? Journal of Economic Perspectives, 17(3), $23-48$.

Eberhardt, M., \& Presbitero, A. F. (2015). Public debt and growth: Heterogeneity and non-linearity. Journal of International Economics, 97, 45 -58.

Essabra-Mensah, E. (2018, July 30). Atta Akyea proposes US\$90bn infrastructure bond. Retrieved from thebftonline.com: https://thebftonline.com/2018/headlines/atta-akyea-proposes-us90bn-infrastructurebond/\#

Gui-Diby, S. L. (2014). Impact of foreign direct investments on economic growth in Africa: Evidence from three decades of panel data analyses. Research in Economics, 68, 248-256.

Hassan, S. U., \& Mamman, A. (2013). External Debt and Economic Growth: Evidence FromNigeria. International Journal of Economics, Business and Finance, 10-23.

International Monetary Fund. (2015). Making Public Investment More Efficient. Washington DC: IMF. Washington DC: International Monetary Fund.

Krugman, P. (1988). Financing vs. forgiving a debt overhang. Journal of development Economics, 29(3), 253-268.

Kuznets, S. (1974). Population, capital, and growth. Heinemann Educational.

McKinnon, R. I. (1973). Money and capital in economic development. Washington, DC: The Brookings Institution.

Megersa, K. A. (2015). The laffer curve and the debt-growth link in low-income Sub Saharan African economies. Journal of Economic Studies, 42(5), 878 - 892.

Mensah, L., Bokpin, G. A., \& Boachie-Yiadom, E. (2018). External Debt institutions and growth. Journal of African Business, 114-132.

Mishra, P. K., Das, K. B., \& Pradhan, B. B. (2009). Credit market development and economic growth in India. Middle Eastern Finance and Economics, 5(3), 92-106.

Mody, A., \& Murshid, A. P. (2011). Growth from International Capital Flows: The Role of Volatility Regimes. IMF Working Paper, WP/11/90.

Ogbeifun, M. I. (2007). The Politics of External Debt Relief: Nigeria's Unique Experience. African Journal of Stability and Development, 1(1), 37-43.

Okada, K. (2013). The interaction effects of financial openness and institutions on international capital flows. Journal of Macroeconomics, 131-143.

Panizza, U., \& Presbitero, A. F. (2014). Public debt and economic growth: is there a causal effect? Journal of Macroeconomics, 41, 21-41.

Pattillo, C. A., Poirson, H., \& Ricci, L. A. (2002). External debt and growth. International Monetary Fund.

Presbitero, A. F. (2008). The Debt-Growth Nexus in Poor Countries: A Reassessment. . The Open-Access, OpenAssessment E-Journal, 1-30.

Sachs, J., McArthur, J., Schmidt-Traub, G., M, K., Bahadur, C., Faye, M., \& G., M. (2004). Ending Africa's Poverty Trap. Brookings Papers on Economic Activit, 146.

Sedik, T. S., \& Sun, T. (2012). Effects of Capital Flow Liberalization-What is the Evidence from Recent Experiences of Emerging Market Economies? IMF Working Paper, WP/12/275.

Solow, R. M. (1956). A Contribution to the Theory of Economic Growth. The Quarterly Journal of Economics, $70(1), 65-94$.

Sulaiman, L. A., \& Azeez, B. A. (2012). Effect of external debt on economic growth of Nigeria. Journal of Economics and Sustainable Development, 3(8), 71-79.

World Bank. (2015). The Africa Infrastructure Diagnostic Report. Washington DC: World Bank .

World Bank. (2017). World Development Indicators. Washington DC: World Bank.

Zaman, R., \& Arslan, M. (2014). The Role of External Debt on Economic Growth: Evidence from Pakistan Economy. Journal of Economics and Sustainable Development, 24.

Zouhaier, H., \& Fatma, M. (2014). Debt and Economic Growth. International Journal of Economics and Financial Issues, 4(2), 440-448. 